\title{
Effect of Online Shopping Credit Evaluation on Customer Purchase Risk: Logistics Service as a Mediator
}

\author{
Ching Kuei Kao ${ }^{1, ~ *, ~ Z h a o ~ N i ~ C h e n ~}{ }^{2}$, Peng Jung $\operatorname{Lin}^{3}$ \\ ${ }^{1}$ Key Laboratory of LNG Industry Chain, School of Transportation, Fujian University of Technology, Fuzhou City, China \\ ${ }^{2}$ Department of Logistics Management, School of Business, Beijing Institute of Technology, Zhuhai City, China \\ ${ }^{3}$ Department of Business Administration, School of Internet Economics and Business, Fujian University of Technology, Fuzhou City, China
}

Email address:

ckkao@fjut.edu.cn (Ching Kuei Kao),277900586@qq.com (Zhao Ni Chen), linpengjung@qq.com (Peng Jung Lin)

${ }^{*}$ Corresponding author

\section{To cite this article:}

Ching Kuei Kao, Zhao Ni Chen, Peng Jung Lin. Effect of Online Shopping Credit Evaluation on Customer Purchase Risk: Logistics Service as a Mediator. American Journal of Theoretical and Applied Business. Vol. 7, No. 1, 2021, pp. 16-29. doi: 10.11648/j.ajtab.20210701.13

Received: March 12, 2021; Accepted: March 22, 2021; Published: March 30, 2021

\begin{abstract}
With the rapid popularization of the Internet in China and equally rapid development of e-commerce, an increasing number of individuals prefer the $\mathrm{C} 2 \mathrm{C}$ e-commerce platform for shopping. Sellers' credit evaluation is one of the important reference values of buyers' online shopping. As the quality of the credit evaluation affects the purchase risks of customers, the C2C e-commerce credit evaluation of online shopping and the purchase risk of customers are studied. This study divides the purchase risk of customers into six dimensions, namely, store risk, product risk, money risk, distribution risk, time risk, and security risk. The effect of $\mathrm{C} 2 \mathrm{C}$ credit evaluation on the purchase risk of consumers is then discussed. Subsequently, the effects of the $\mathrm{C} 2 \mathrm{C}$ credit rating system and customer purchase risk on the purchase intention of customers are further explored. Furthermore, logistics services, as an important part of $\mathrm{C} 2 \mathrm{C}$ e-commerce transactions, are analyzed as a mediator in this research. This study uses regression analysis to test the research hypotheses. Results corroborate that improving the credit evaluation of online shopping can reduce the purchase risk of customers. Logistics service has mediating effects on the credit evaluation of online shopping and the purchase risk of customers. The latter can be reduced through logistics service, thereby further increasing the purchase intention of customers. Among the dimensions of customer purchase risk, product risk, money risk, delivery risk, and time risk are the most significant factors affecting the purchase intention of customers. Increasing the purchase intention of customers by reducing these four risks is possible. The logistics service affects the purchase risk and intentions of customers as well. The mediating effect reduces the purchase risk of customers and improves the ability of logistics service to increase the purchase intention of customers. Moreover, improving credit evaluation can enhance the purchase intention of customers. Logistics service has a mediating effect on the credit evaluation of online shopping and purchase intention of customers. That is, improving the credit evaluation of online shopping can improve the logistics service, thereby increasing the purchase intention of customers. On the basis of these conclusions, this study provides sellers and logistics service providers with constructive suggestions to improve the $\mathrm{C} 2 \mathrm{C}$ e-commerce platform.
\end{abstract}

Keywords: Credit Evaluation, Purchase Risk, Purchase Intention, Logistics Service, Mediating Effect

\section{Introduction}

Since the 1990s, China's e-commerce has developed rapidly, $\mathrm{C} 2 \mathrm{C}$ online shopping has advanced greatly, and online shopping has attracted growing attention [1]. According to the 41st Statistical Report on the Development of the Internet in China, the number of Chinese Internet users has reached 772 million, and the penetration rate has reached $55.8 \%$ as of
December 2017, exceeding the global average by 4.1 percentage points [2]. These figures show that the rapid development of the Internet in China has also promoted that of $\mathrm{C} 2 \mathrm{C}$ e-commerce. Unlike traditional shopping, e-commerce is not limited by time and place, making shopping convenient. In 2015, the number of online shoppers in China was 145 million, with an increase of 23.3 million over 2014 and an annual growth rate of $19.1 \%$. At the same time, the transaction scale of the Chinese online shopping market continued to expand, 
the total number of transactions reached 25.6 billion times, and the average number of transactions per person reached 62 times in 2015 [3]. These data reveals that online shopping is becoming increasingly popular with consumers. Consumers can access the Internet by themselves and then can search for their favorite products through the e-commerce platform. They can complete online transactions through electronic payment, logistics services, and after-sales services of the e-commerce platform. Although the $\mathrm{C} 2 \mathrm{C}$ e-commerce is becoming more mature, the credit issue of e-commerce remains a main concern for consumers. According to the monitoring data of China's e-commerce complaints and rights protection public service platform, the complaints from retail e-commerce accounted for $76.24 \%$ of all complaints in the first half of 2017, including those against C2C e-commerce platforms [4]. From the top ten online complaints on retail e-commerce in 2017, the proportion of delivery problems was the highest, accounting for $19.92 \%$; the difficulty of returning and replacing goods accounted for $13.29 \%$; sales of fakes accounted for $8.23 \%$ and non-refundable deposits on e-commerce platforms accounted for $3.47 \%$ [3]. In addition, e-commerce continues to have problems with service issues, such as delivery and refunds, and integrity issues, such as online fraud, online sales, and false promotions. The underlying reason for these problems is sellers' credit evaluation.

In $\mathrm{C} 2 \mathrm{C}$ e-commerce transactions, credit evaluation is an important guarantee to regulate the transaction behavior of buyers and sellers. Online credit evaluation is shown to buyers by collecting accumulated credit evaluation records from sellers; buyers can then make purchase decisions by referring to sellers' credit evaluations and evaluation records under product details [5]. For consumers shopping online, credit evaluation is crucial to online transactions. As online shopping consumers cannot access the actual product, the product information that consumers see on the website is limited. Buyers can feel the authenticity of the product through consumers' experience, evaluation, and rating of the product. When shopping online, consumers can obtain information about products to make purchasing decisions from the evaluation of products and sellers or through the feelings of other consumers. According to the survey data from the China Internet Network Information Center in 2015, the most important factor influencing the purchase decision of online shoppers is the online reputation of the product, accounting for $77.5 \%$. It is followed by the price of the product and the credibility of the website and merchants, which are $72.2 \%$ and $68.7 \%$, respectively. The credibility of the website and merchants are mainly displayed through the credit evaluation of the product [3]. Evidently, credit evaluation has a significant effect on consumer purchase decisions.

Consumer purchase decision comes from consumer satisfaction, that is, the possibility of consumers buying a certain product. In online shopping, consumers mainly browse product information and understand related services of products through the website. Online purchase intention refers to the possibility that consumers can purchase the product or service after they understand the website information and product details and services [6]. Jing and Zhou believed that consumers communicate with online sellers through the Internet and use the network to place orders and pay online [7]. These operations make consumers feel the practicability of online shopping. The ease of online operation, order placement, and cancellation make consumers feel the convenience of online shopping. The practicality and convenience of online shopping constitute the interests of online shopping for consumers. However, when shopping online, consumers must consider not only their own interests but also the risks that may exist in online shopping, that is, the purchase risk. Consumer interests and purchase risk together affect the purchase intention of consumers. Pavlou presumed that online shopping provides consumers with a convenient and fast way to shop [8]. However, compared with traditional offline shopping, online shopping comes with new purchasing risks, such as leakage of personal information, theft of consumer passwords, lack of quality assurance of products, untimely delivery after payment, or violence during delivery. The existence of these risks seriously restricts the willingness of consumers to buy and affects their purchase intention.

In addition to online purchase risks, logistics services affects consumers' willingness to buy online. Han et al. pointed out that the human factor is extremely important in the entire online shopping service process [9]. In the logistics delivery of goods, the quality and service ability of the receiving personnel have an important influence on whether the goods can be delivered to the hands of the logistics service provider. During logistics services, the service ability and attitude of the staff determine the safety of goods and high efficiency of logistics processes. In the final distribution process, the attitude and service ability of the staff determine the satisfaction of final consumer, which has a direct effect on logistics service quality [9]. Therefore, the management of logistics service quality cannot ignore the management of people. The credit evaluation of online shopping, as well as logistics services, affects consumer purchase risk.

At present, the credit evaluation of $\mathrm{C} 2 \mathrm{C}$ e-commerce has become an important factor restricting the healthy development of e-commerce. For example, an imperfect evaluation system, low credible evaluations, inadequate supervision and management, and weak evaluation interactivity and fragmentation have led to difficulties in the development of $\mathrm{C} 2 \mathrm{C}$ e-commerce, and these credit issues have also affected consumer purchase risks [1]. When consumers make online purchases, they not only pay attention to the price of the product but also more consider the risks arising from online shopping, and these purchase risks affect consumers' purchase decisions. Therefore, this study focuses mainly on the effect of credit evaluation of $\mathrm{C} 2 \mathrm{C}$ e-commerce on consumer purchase risk. As the distribution of goods for $\mathrm{C} 2 \mathrm{C}$ online shopping must be completed through logistics services, such services are considered a mediator. This study also explores the effect of logistics services on the relationship between credit evaluation of $\mathrm{C} 2 \mathrm{C}$ e-commerce and consumer 
purchase risk.

\section{Literature Review}

This section contains two parts. The first elaborates the meaning of consumer purchase risk and sorts related evaluation aspects and indicators to measure consumer purchase risk. The second explains logistics services.

\subsection{Purchase Risk of Consumers}

With the rapid popularization of $\mathrm{C} 2 \mathrm{C}$ e-commerce, the risks of e-commerce have attracted increasing public attention. The purchase risk of consumers has a significant effect on their purchase decisions and behaviors [10]. The purchase risk in the present study refers to the risk of online shopping by consumers. Online shopping refers to the entire process of consumers selecting products by browsing the stores on the $\mathrm{C} 2 \mathrm{C}$ website, then making online payments, and finally sending the tangible and intangible products to the designated receiving place by the seller through the designated logistics company. Online purchase risk mainly refers to the risks that consumers encounter while online shopping [10]. From a psychological perspective, Bauer considered that consumers will recognize that the results of their actions will produce unpredictable uncertainty, so consumer behavior can be regarded as a risk burden [11]. Engel viewed that consumer behavior is goal oriented and that purchase risks are created when consumers realize that their purchases fail to meet their purchase goals [12].

According to relevant literature, consumer purchase risk has multiple aspects. Hofacker and Murphy proposed that consumer purchase risk can be divided into five aspects, namely, time risk, store risk, security risk, brand risk, and privacy risk [13]. O'Mara et al. thought that consumer purchase risk can be divided into face risk and product risk [14]. Kaplan et al. divided consumer purchase risk into four aspects, which are money risk, performance risk, physical risk, and social risk [15]. Ye and Zhou divided consumer purchase risk into five aspects, namely, the risk of unreliability of online stores, the risk of product effects, the risk of loss of money, the risk of delivery, and the risk of theft of personal information [10]. According to the comprehensive arrangement of the literature, the following six aspects are proposed for consumer purchase risk: store risk, time risk, product risk, money risk, delivery risk, and personal information security risk. The definition of each facet is shown in Table 1.

Table 1. Definition of purchase risk of consumers.

\begin{tabular}{|c|c|c|c|}
\hline $\begin{array}{l}\text { Aspect of } \\
\text { Risk }\end{array}$ & Classification of risk & Literature definition & Definition in this study \\
\hline Store risk & $\begin{array}{l}\text { Risk of unreliability of } \\
\text { online stores [10] }\end{array}$ & $\begin{array}{l}\text { When shopping at physical store, consumers feel reassured because the } \\
\text { product is touchable. Relatively speaking, consumers feel nervous because } \\
\text { they cannot see the physical items when shopping online. } \\
\text { Consumers are worried that online stores are only for their own interests or } \\
\text { objectively incapable of providing online retail services that consumers desire. }\end{array}$ & $\begin{array}{l}\text { Behaviors of online stores show that } \\
\text { these stores only consider their own } \\
\text { interests and are unable to provide the } \\
\text { online retail services that consumers } \\
\text { desire. }\end{array}$ \\
\hline \multirow{6}{*}{ Product risk } & $\begin{array}{l}\text { Brand risk [13] } \\
\text { Product risk [14] }\end{array}$ & $\begin{array}{l}\text { Consumers may have concerns about unfamiliar brands. } \\
\text { Consumers are concerned about the inability to effectively guarantee product } \\
\text { performance, quality, or service. }\end{array}$ & \multirow{6}{*}{$\begin{array}{l}\text { Consumers are concerned that the } \\
\text { product quality and after-sales } \\
\text { service cannot be effectively } \\
\text { guaranteed and cannot meet } \\
\text { expectations. }\end{array}$} \\
\hline & Face risk [14] & $\begin{array}{l}\text { Consumers worry that the products they buy cannot meet expectations in that } \\
\text { the products they buy cannot be recognized by others and bear greater face } \\
\text { risk. }\end{array}$ & \\
\hline & Performance risk [15] & $\begin{array}{l}\text { The product functions fail to achieve the expected effects of consumers' } \\
\text { purchase costs. }\end{array}$ & \\
\hline & Physical risk [15] & When the product is not ideal or has defects, it may cause harm to consumers. & \\
\hline & $\begin{array}{l}\text { Risk of product effects } \\
{[10]}\end{array}$ & $\begin{array}{l}\text { Consumers are worried that the quality and value of the purchased products } \\
\text { will not achieve the expected effect. }\end{array}$ & \\
\hline & Social risk [15] & The products purchased by consumers are not recognized by others. & \\
\hline \multirow[b]{2}{*}{ Money risk } & Money risk [15] & The value of the product does not match the cost paid. & \multirow{4}{*}{$\begin{array}{l}\text { Consumers may incur monetary loss } \\
\text { or additional expenses for online } \\
\text { shopping. } \\
\text { Consumers are concerned about the } \\
\text { damage and loss of products that may } \\
\text { be caused during delivery. } \\
\text { Consumers spend too much time } \\
\text { searching for information or waiting } \\
\text { for the completion of goods } \\
\text { transactions when shopping online. }\end{array}$} \\
\hline & $\begin{array}{l}\text { Risk of loss of money } \\
{[10]}\end{array}$ & $\begin{array}{l}\text { Consumers worry that online shopping may have to bear more monetary } \\
\text { losses. }\end{array}$ & \\
\hline Delivery risk & Risk of delivery [10] & $\begin{array}{l}\text { Consumers worry that the goods may be damaged, lost, and delayed during } \\
\text { delivery. }\end{array}$ & \\
\hline Time risk & Time risk [13] & $\begin{array}{l}\text { Consumers spend too much time shopping online or searching for product } \\
\text { information. }\end{array}$ & \\
\hline \multirow{3}{*}{$\begin{array}{l}\text { Personal } \\
\text { information } \\
\text { security risk }\end{array}$} & Security risk [13] & Consumers worry that personal information will be leaked and stolen. & \multirow{3}{*}{$\begin{array}{l}\text { Personal information of consumers } \\
\text { may be leaked or abused during } \\
\text { online shopping. }\end{array}$} \\
\hline & Privacy risk [13] & $\begin{array}{l}\text { Consumers worry that the shopping information left on shopping websites } \\
\text { may be abused. }\end{array}$ & \\
\hline & $\begin{array}{l}\text { Risk of theft of } \\
\text { personal information } \\
{[10]}\end{array}$ & $\begin{array}{l}\text { Consumers worry that personal information may be leaked or misused during } \\
\text { online shopping. }\end{array}$ & \\
\hline
\end{tabular}


If $\mathrm{C} 2 \mathrm{C}$ e-commerce companies want to gain a competitive advantage, they must work hard to increase the willingness of consumers to buy. The two forms of online shopping products are tangible and intangible products. The former are products that can be accessed through the body, and the latter pertain to services. Consumers buying products online, whether they are tangible or intangible, face purchase risks, and higher purchase risks affect their willingness to buy.

\subsection{Logistics Services}

In addition to online purchase risks, logistics services affects purchase intent. The traditional definition of logistics services is based on 7Rs theory with time and place utility [16]. That is, in the process of providing logistics services, enterprises deliver goods to the right place and right environment at the right time and deliver the right amount of right product with the right price and right condition, thereby bringing added value to the product. With the development of the economy, logistics services are turning to evaluate the effect of logistics services on customer satisfaction from the perspective of customers. Mentzer et al. investigated the process and timeliness of logistics services and proposed the logistics service quality (LSQ) model, which is consumer oriented [17].

The LSQ model can be divided into three aspects according to the time course of logistics services: ordering process, receiving process, and final satisfaction. The ordering process includes the communication work between the seller of the online shop and the customer, the provision of the product information, and the ordering procedure. The ordering process is the starting point of logistics, which has a greater effect on consumer shopping experience. The quality of this process also directly affects the experience of the receiving process. The receiving process includes the accuracy of the order, the integrity of the goods, and the quality of the order processing. In $\mathrm{C} 2 \mathrm{C}$ online shopping, placing an order on the Internet is the ordering process. In this process, consumers can communicate with the seller to request the logistics service of the goods, and the results of the negotiation affect the willingness of consumer to buy. Then, the goods are distributed from the seller to the buyer through logistics service. If the goods have problems during the logistics distribution process, the customer can request the logistics company to handle it, leading to the error handling service. Error handling is at the end of the receiving process, and timeliness is directly affected by error handling. Finally, timeliness and error handling affect consumer satisfaction. For consumers, the accuracy of the goods shipped by the seller and the integrity of the goods in the distribution process affect the purchase risk of consumers. At the same time, the time efficiency of the ordering process has a direct effect on customer satisfaction. Therefore, this study takes logistics service as the mediator to discuss the effect of logistics service on the relationship between $\mathrm{C} 2 \mathrm{C}$ e-commerce credit evaluation and consumer purchase risk.

\section{Research Method}

This section first introduces the research framework of this study, then explains the research hypothesis, and finally describes the design process of the questionnaire.

\subsection{Research Framework}

When consumers are shopping online, credit evaluation is an important reference for them to make product selections. The credit evaluation of seller may have an effect on consumers' purchase risk and, in turn, their willingness to purchase. The purchase behavior of online shopping must be completed through logistics services. Therefore, this study takes the credit evaluation of online shopping, the purchase risk of consumers, logistics services, and the purchase intention of consumers as research variables. The research framework is shown in Figure 1, and these four variables are explained below.

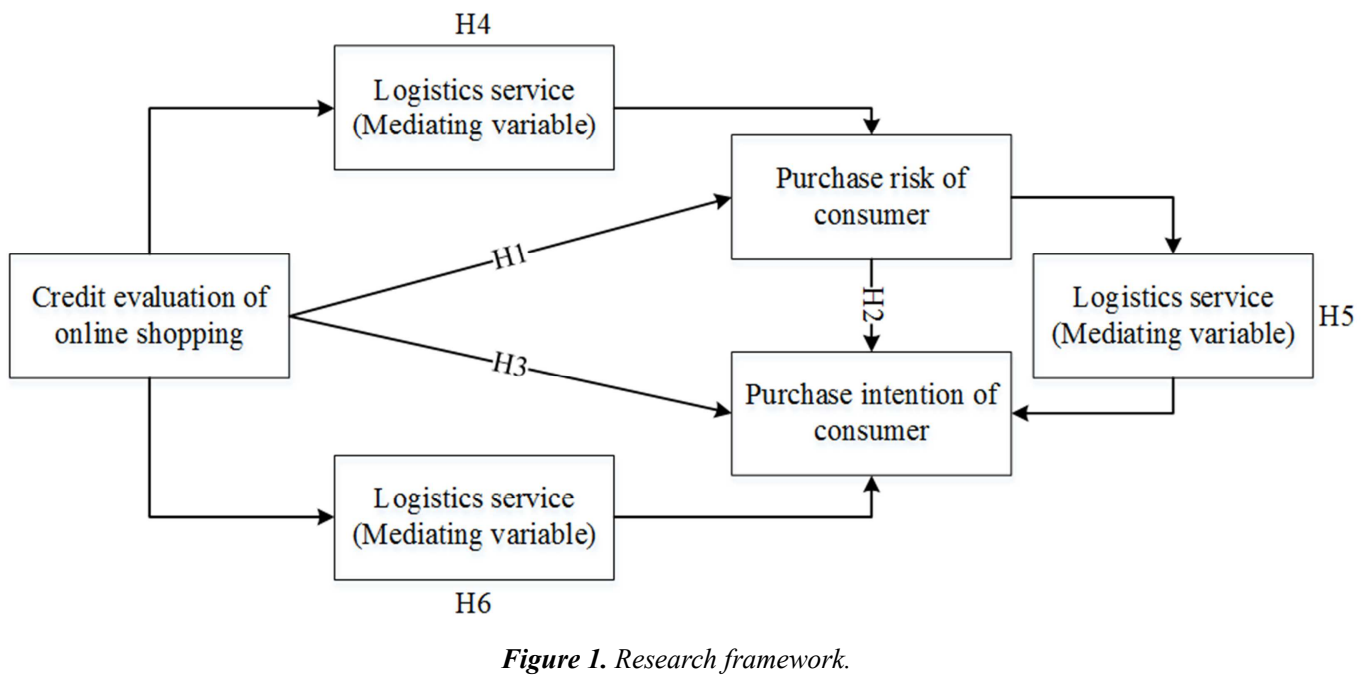

\subsubsection{Credit Evaluation of Online Shopping}

The operation principle of the $\mathrm{C} 2 \mathrm{C}$ credit evaluation of online shopping is that the buyer can evaluate the seller after the online transaction is completed, such as the seller's service attitude, user experience, delivery speed, and product quality, 
to comprehensively evaluate the seller's store or product. The accumulated feedback information is sorted and calculated by the credit evaluation management system according to the system background algorithm to obtain the credit value of seller, and the buyer can make a purchase decision based on this credit value [5].

\subsubsection{Purchase Risk of Consumers}

In response to the purchase risks of consumer, this study proposes the following six aspects: store risk, product risk, money risk, delivery risk, time risk, and personal information security risk. These dimensions are described in detail in Table 1.

\subsubsection{Logistics Services}

Logistics services refer to the transfer service of goods after the buyer places an order during online purchase. The goods provided by the online seller depart from the seller and are delivered to the place designated by the buyer.

\subsubsection{Purchase Intention of Consumers}

When shopping online, consumers can learn about the goods and services of the seller through the shopping website. The online purchase intention refers to the possibility that the consumer purchases a certain product after understanding the product information through the shopping website.

\subsection{Research Hypothesis}

This study aims to explore the relationship between the credit evaluation of online shopping, the purchase risk of consumers, logistics services, and the purchase intention of consumers. Six research hypotheses are proposed and explained below.

\subsubsection{Credit Evaluation of Online Shopping Has a Negative Effect on the Purchase Risk of Consumers}

In $\mathrm{C} 2 \mathrm{C}$ e-commerce, buyers and sellers lack certain trust because confirming each other's true identities is difficult. Credit evaluation can help the buyer to learn more about the seller's situation and product information. The buyer can also be more at ease when choosing the seller and product during online shopping. The buyer can obtain more information about the credit evaluation through various methods to evaluate the credit of various sellers. A buyer can first understand the credit evaluation of other buyers on the seller or the product before buying product. This information can help buyers compensate for the information asymmetry when shopping online and related moral hazards. Therefore, the existence of credit evaluation has promoted the development of $\mathrm{C} 2 \mathrm{C}$ e-commerce.

However, many factors affect $\mathrm{C} 2 \mathrm{C}$ e-commerce. For example, buyers and sellers' perception of the products traded vary, the seller sells products that do not match the real information, a fraudulent seller sells counterfeit and shoddy goods, or the $\mathrm{C} 2 \mathrm{C}$ website has integrity problems. These factors hinder the development of e-commerce and at the same time pose a certain threat to the safety of consumers' purchases and increase their purchase risk. Chen found that the perfect credit evaluation can reduce the purchase risk of consumers [18].

\subsubsection{Purchase Risk of Consumers Has a Negative Effect on the Purchase Intention of Consumers}

In an online shopping environment, consumers can only make decisions based on the subjective judgment of various information. Determining the consequences of making purchases is impossible. The uncertainty comes from the uncertainty of consumers about the quality of products, the uncertainty of payment security, and the inability to guarantee after-sales service. When consumers are more sensitive to risk, they often give up buying online. Garretson and Clow considered that when consumers cannot predict the purchase result and are uncertain, the perceived risk affects their purchase decisions [19]. Lack of product information raises doubts about product information, thus increasing the risks perceived by consumers. The uncertainty of consumer perception and the amount of product information are greatly correlated. When perceived risk increases, the purchase intention of consumers decreases.

\subsubsection{Credit Evaluation of Online Shopping Has a Positive Effect on the Purchase Intention of Consumers}

Online stores have many types. The same product can be sold in different stores, but the quality of the same product is difficult to distinguish given the difference between stores. This situation causes consumers trouble when buying products online. Fraud is also serious in online shopping, which makes consumers worry about online shopping and affects their willingness to buy. $\mathrm{C} 2 \mathrm{C}$ credit information evaluation can reduce the drawbacks of online shopping. $\mathrm{Wu}$ et al. analyzed that the reputation evaluation system has a significant effect on online shopping [20]. Liu found that credit evaluation has a significant effect on buyers' repeated purchases [21].

\subsubsection{Logistics Services Have a Mediating Effect on the Relationship Between the Credit Evaluation of Online Shopping and the Purchase Risk of Consumers}

The logistics service of online shopping refers to the service through which the seller will deliver the goods to the point designated by the buyer through the express logistics enterprise when the buyer shops online. Yu et al. proposed that the express logistics services of online shopping can be evaluated, that is, buyers can evaluate the score of logistics services through the shopping platform after receiving the goods [22]. For buyers, the user experience of logistics services is an important part of the overall evaluation of $\mathrm{C} 2 \mathrm{C}$ e-commerce services. Good logistics service quality can help improve the impression of buyers on products, sellers, and e-commerce platforms. Conversely, poor logistics service quality can reduce the overall impression of buyers on sellers. At present, $\mathrm{C} 2 \mathrm{C}$ e-commerce distribution is characterized by small batches and multiple frequencies. The scale of sellers is small, and their financial capacity is inadequate to establish their own logistics distribution system. Therefore, the designated third-party logistics provider is selected to provide 
logistics service cooperation. However, when credit problems occur, such as damage of goods, theft of goods, and undeliverable goods, the seller or buyer is often responsible for the risks. Sellers can be held responsible for their actions and then reduce the purchase risk of buyer to obtain an improved credit evaluation. To improve the credit evaluation, the seller may request that the designated logistics service provider must also be responsible for its behavior and provide good service quality to the buyer. This study considers that improving credit evaluation can first improve the quality of logistics services and then reduce the purchase risk of buyers. That is, improving credit evaluation can not only directly reduce the purchase risk of buyers but also indirectly reduce the purchase risk of buyers by improving the quality of logistics services.

\subsubsection{Logistics Services Have a Mediating Effect on the Relationship Between the Purchase Risk of Consumers and Purchase Intention of Consumers}

In the $\mathrm{C} 2 \mathrm{C}$ e-commerce transaction link, consumers' purchase risk greatly affects their willingness to buy. When the purchase risk is relatively large, consumers often give up buying online. As an important part of $\mathrm{C} 2 \mathrm{C}$ transactions, logistics services are necessary for sellers to deliver goods to buyers. In the current $\mathrm{C} 2 \mathrm{C}$ electronic transaction mode, logistics services are generally provided by third-party logistics. If the goods are damaged during the logistics process or the logistics service personnel fail to provide good services, then the purchase risk of consumers increases. To reduce the purchase risk, the seller will inevitably supervise third-party companies to improve logistics services and deliver the goods safely and effectively to buyers. He and Lv showed that the quality of logistics services significantly affects the purchase intention of consumers [23]. When the buyer receives the goods, whether the goods are intact will affect the buyer's willingness to buy. If the buyer receives the goods and finds that the goods have been violently transported, the buyer's willingness to buy on the $\mathrm{C} 2 \mathrm{C}$ platform will decrease. This study assumes that to reduce the purchase risk of consumers, the logistics services must be improved, thereby increasing consumers' willingness to purchase. That is, reducing consumers' purchase risk can directly increase their willingness to purchase. Consumer purchase risk can indirectly increase consumers' willingness to purchase by ensuring that good logistics services are provided.

\subsubsection{Logistics Services Have a Mediating Effect on the Relationship Between the Credit Evaluation of Online Shopping and the Purchase Intention of Consumers}

Logistics service refers to the delivery of goods to the buyer's designated place after the order is placed. The goods provided by the seller depart from the seller and are delivered to the buyer's designated place. Express logistics services are evaluable. For buyers, the experience of using logistics services is an important part of their overall evaluation of $\mathrm{C} 2 \mathrm{C}$ e-commerce services. Good logistics service quality can help improve buyers' perception of products, sellers, and e-commerce platforms. Poor logistics service quality can reduce the overall impression of buyers on sellers. In $\mathrm{C} 2 \mathrm{C}$ e-commerce transactions, sellers strive to provide better logistics services to improve their own credit evaluation. Tang believed that credit evaluation helps buyers better understand the credit status of the objects in the transaction, helps users in judging the reputation of the seller in the transaction, and improves the success rate of online transactions [24]. Therefore, the seller's credit evaluation affects the purchase intention of consumers. When the seller's credit evaluation is high, the purchase intention of consumers also increases. This study assumes that if the seller wants to improve its credit evaluation, it will first improve the quality of logistics services and ultimately consumers' willingness to buy. Credit evaluation can "indirectly" increase consumers' willingness to purchase by improving the quality of logistics services.

\subsection{Questionnaire Design}

\subsubsection{Description of Questionnaire Variables}

This study explores the relationship between credit evaluation, consumer purchase risk, logistics services, and purchase willingness through a questionnaire survey. These measurement items of the four variables results in a total of 35 questions.

(1) Credit evaluation of online shopping: After the online transaction is completed, the buyer can evaluate the seller, including the seller's service attitude, user experience, delivery speed, and product quality to comprehensively evaluate the seller's shop or product. The feedback information is sorted and calculated by the credit evaluation management system according to the background algorithm of the system to obtain the seller's credit value, and the buyer can make a purchase decision based on the seller's credit value [5].

(2) Purchase risk of consumers: This study proposes the following six dimensions of purchase risk: store risk, product risk, money risk, delivery risk, time risk, and personal information security risk. The questionnaire items are explained below. Store risk refers to the behaviors of online stores show that these stores only consider their own interests and are unable to provide consumers with the online retail services that they want. Money risk refers to the possible loss or extra cost of consumers to online shopping. Product risk refers to product function, quality, and after-sales service not being effectively guaranteed and the fear of falling short of expectations. Distribution risk refers to consumers' concerns about product damage and loss that may be caused by the distribution of goods. Time risk means that consumers spend too much time searching for information or waiting for goods transactions to be completed when they are shopping online. Personal information security risks mean that consumers' personal information may be leaked or abused during online shopping.

(3) Logistics service: Logistics service refers to the goods transfer service through which the goods specified by the buyer from the seller after the order is placed by the 
buyer at the time of online purchase.

(4) Purchase intention of consumers: Willingness to buy refers to the possibility of consumers purchasing goods on the $\mathrm{C} 2 \mathrm{C}$ platform.

The questionnaire design uses a Likert scale score of 1 to 5 , with $1=$ =strongly disagree, $2=$ disagree, $3=$ general, 4=agree, and $5=$ strongly agree. A higher score indicates a higher degree of approval.

After completing the design of the questionnaire, the research data were collected based on online surveys. The questionnaires were distributed and collected through network platform. Students are an important group of online shopping and consumption, thus the object of the questionnaire is mainly college students. Finally, 78 valid questionnaires were collected.

\subsubsection{Verification Analysis of Research Hypothesis}

In this study, regression analysis was used to test the research hypotheses, including the relationship between the credit evaluation of online shopping and the purchase risk of consumers, that between the purchase risk of consumers and the purchase intention of consumers, and that between the credit evaluation of online shopping and the purchase intention of consumers. Finally, the effect of logistics services as mediator was verified. Mediating effect refers to the effect of an independent variable on the effect of dependent variable through mediator. The three cases are no mediating effect, partial mediating effect, and full mediating effect. The steps of the mediating effect analysis are shown in Figure 2 and are explained below [25, 26].

Table 2. Variables and measurements items of questionnaire.

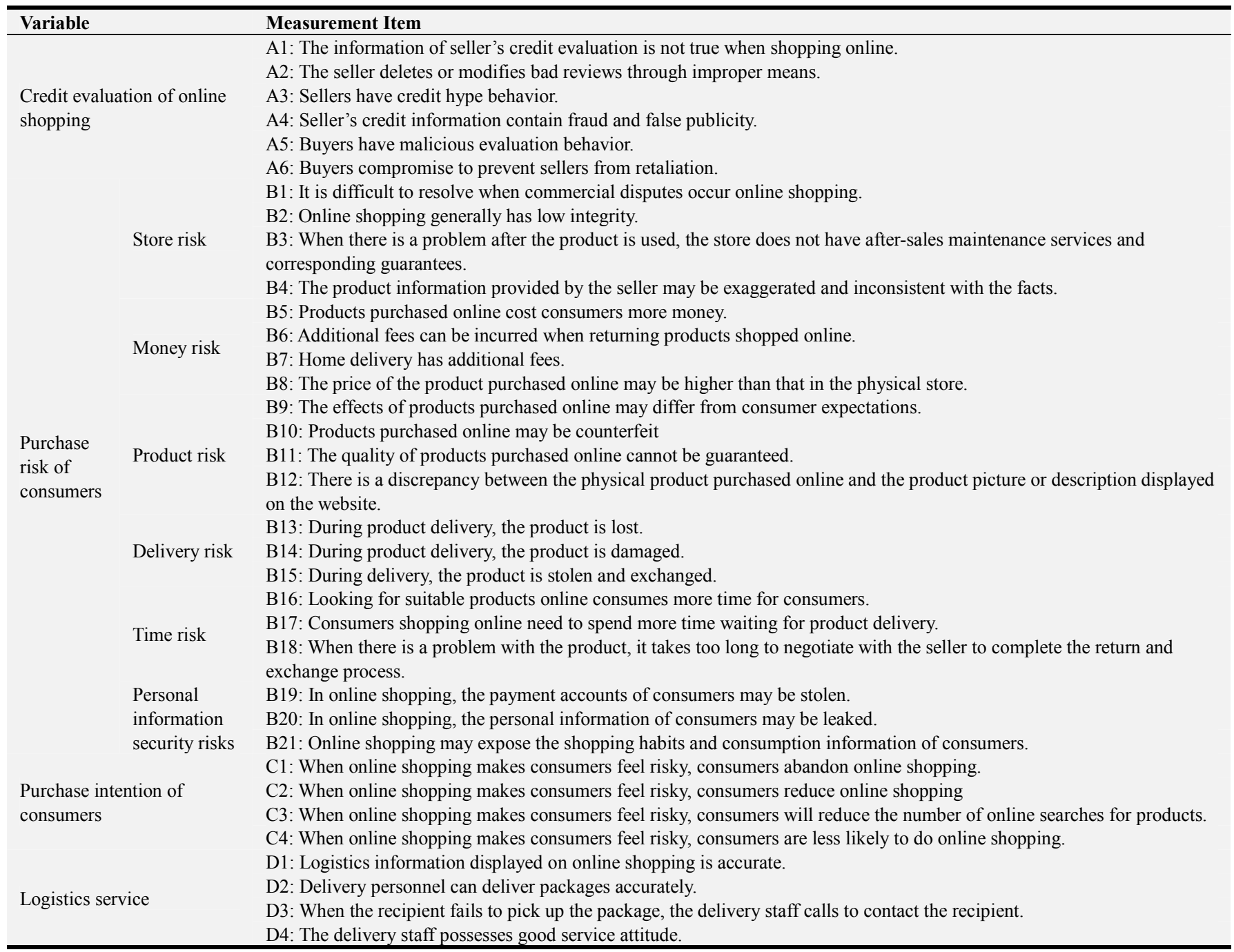

Step 1. This step is to establish a linear regression model $Y=\beta_{0}^{1}+\beta_{X}^{1} X$ that predicts the dependent variable $Y$ with the independent variable $X$. The total effect of $X$ on $Y$ is the estimate of $\beta_{X}^{1}\left(\hat{\beta}_{X}^{1}\right)$. If the regression coefficient $\beta_{X}^{1}$ is significantly different from zero, then a significant relationship exists between the independent and dependent variables. Thus, the null and alternative hypotheses are given as $\mathrm{H}_{0}: \quad \beta_{X}^{1}=0$ and $\mathrm{H}_{1}: \quad \beta_{X}^{1} \neq 0$, respectively. If the hypothesis testing result of regression coefficient $\beta_{X}^{1}$ is not significant, then the mediating effect analysis is stopped. If the hypothesis testing result of regression coefficient $\beta_{X}^{1}$ is 
significant, then the second step is performed.

Step 2. This step is to establish linear regression models $M=\beta_{0}^{2}+\beta_{X}^{2} X$ that predicts the mediating variable $M$ with the independent variable $X$. If the hypothesis testing result of regression coefficient $\beta_{X}^{2}$ is not significant, then the analysis of the mediating effect is stopped. If the hypothesis testing result of regression coefficient $\beta_{X}^{2}$ is significant, then the third step is carried out.

Step 3. This step is to establish a linear regression model $Y=\beta_{0}^{3}+\beta_{X}^{3} X+\beta_{M}^{3} M$ that predicts the dependent variable $Y$ together with the independent variable $X$ and the mediating variable $M$. The direct effect of $X$ on $Y$ is the estimate of $\beta_{X}^{3}$ ( $\hat{\beta}_{X}^{3}$ ), and the indirect effect of $X$ through $M$ on $Y$ is $\hat{\beta}_{X}^{2} \times \hat{\beta}_{M}^{3}$, where $\hat{\beta}_{X}^{2}$ is the estimate of $\beta_{X}^{2}$ and $\hat{\beta}_{M}^{3}$ is the estimate of
$\beta_{M}^{3}$. If the hypothesis testing results of regression coefficient $\beta_{X}^{2}$ and $\beta_{M}^{3}$ are significant, then the mediating effect is significant. If the hypothesis testing result of regression coefficient $\beta_{X}^{3}$ is not significant and the estimate of $\beta_{X}^{3}$ is close to zero, then the mediating variable $M$ has a perfect mediating effect. If the hypothesis testing result of regression coefficient $\beta_{X}^{3}$ is significant and the estimate of $\beta_{X}^{3}$ is less than the estimate of $\beta_{X}^{1}$ in the first step, then the mediating variable $M$ has a partial mediating effect. The mediating proportion is defined as the dimensionless proportion of the effect of $X$ on $Y$ mediated through $M$, and it is equal to the indirect effect divided by the total effect $\left(\left(\hat{\beta}_{X}^{2} \times \hat{\beta}_{M}^{3}\right) / \hat{\beta}_{X}^{1}\right)$. The total effect is equal to the direct effect plus the indirect $\operatorname{effect}\left(\hat{\beta}_{X}^{1}=\hat{\beta}_{X}^{3}+\hat{\beta}_{X}^{2} \times \hat{\beta}_{M}^{3}\right)$.

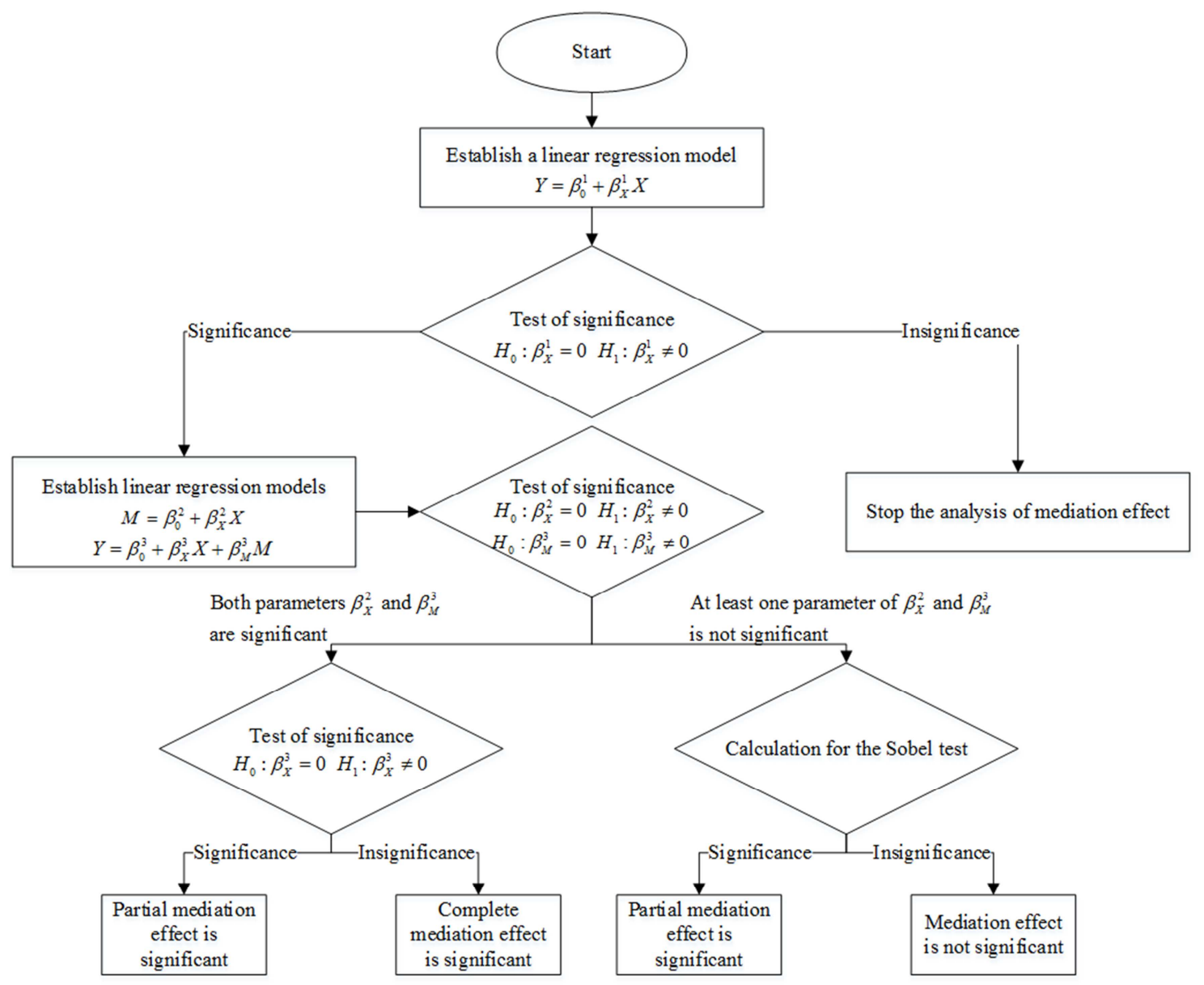

Figure 2. Analysis process of mediating effect.

\section{Data Analysis}

\subsection{Validity Analysis}

This study uses factor analysis to analyze the validity of various aspects of purchase risk.

First, the KMO and Bartlett's tests are performed to confirm whether the data collected from the questionnaire is suitable for factor analysis. Table 3 shows the results of KMO and Bartlett's tests. The KMO value of the collected data is 0.875 , and the p-value of Bartlett's test is 0.000 (representing less than 0.001). The results indicate that the data collected from the questionnaire are suitable for factor analysis.

Table 4 is the rotated component matrix using varimax rotation with Kaiser normalization. Questionnaire items are deleted when the factor load is less than $0.4[27,28]$. 
Table 4 reveals that the factor loading of each risk factor indicator is greater than 0.4 , and the commonality of all risk factor indicators is greater than 0.5 , thus all risk factor indicators are retained. The results show new six research dimensions, namely, product risk, personal information security risk, money risk, delivery risk, time risk, and store risk. These dimensions are basically consistent with the original risk aspects in Table 2. The average communality is 0.743 , which indicates that the content of the risk factor indicators of each risk aspect in the questionnaires conforms to the research structure. The new measurement dimensions of the purchase risk of consumers are defined as follows:

1) Product risk: five questions, including B7, B9, B10, B11, and B12, which refer to consumers' worries about product functions and after-sales service not being effectively guaranteed to meet expectations.

2) Personal information security risks: three questions, including B19, B20, and B21, which refer to consumers' concerns that their personal information may be stolen during online shopping.

3) Money risk: four questions, including B1, B2, B3, and B4, which refer to consumers' concerns about the possible monetary loss or extra cost of online shopping.

4) Delivery risk: three questions, including B13, B14, B15, which refer to consumers' concerns about product damage and loss that may be caused during delivery.

5) Time risk: three questions, including B16, B17, B18, which mean that consumers spend too much time searching for information or waiting for the completion of the goods transaction when shopping online.

6) Store risk: three questions, including B3, B4, and B8, which refer to consumers' worries that online stores only consider their own interests or are unable to provide the online retail services consumers desire.

\subsection{Reliability Analysis}

This research focuses on the four dimensions of the credit evaluation of online shopping, the purchase risk of consumers, the purchase intention of consumers, and logistics services. Cronbach's $\alpha$ coefficient is used to measure the internal consistency of the items in each dimension. In Table 5, the overall Cronbach's $\alpha$ coefficient of the credit evaluation of online shopping, the purchase risk of consumers, the purchase intention of consumers, and logistics services are 0.834 , $0.926,0.863$, and 0.786 , respectively. The minimum value of overall Cronbach's coefficient for these four facets is 0.786 , indicating that the reliability of the questionnaire is good [29].

\subsection{Analysis of Research Hypotheses}

$\mathrm{H} 1, \mathrm{H} 2, \mathrm{H} 3, \mathrm{H} 4, \mathrm{H} 5$, and $\mathrm{H} 6$ are proposed for the research, and they are verified and analyzed as follows.

\subsubsection{Relationship Between the Credit Evaluation of Online Shopping and the Purchase Risk of Consumers}

Regarding the relationship between the credit evaluation of online shopping $\left(V_{C E}\right)$ and the purchase risk of consumers $\left(V_{P R}\right)$ and the mediating effect of logistics services $\left(M_{L S}\right)$ between credit evaluation of online shopping $\left(V_{P R}\right)$ and the purchase risk of consumers $\left(V_{C E}\right)$, the hypotheses are as follows:

$\mathrm{H} 1$ : Credit evaluation of online shopping has a negative effect on the purchase risk of consumers.

H4: Logistics services have a mediating effect on the relationship between the credit evaluation of online shopping and the purchase risk of consumers.

According to the results in Table 6 , the estimate of $\mathrm{B}_{1}$ is -0.382 , and the regression equation that predicts $V_{P R}$ with $V_{C E}$ is $V_{P R}=0.771-0.382 V_{C E}$. When the score of credit evaluation of online shopping decreases, the score of the purchase risk of consumers increases. In addition, the p-value is less than $\alpha$ (significance level $=0.05$ ). Thus, the result of the hypothesis testing $\left(\mathrm{H}_{0}: \mathrm{B}_{1}=0\right)$ is rejection, that is, $\mathrm{B}_{1} \neq 0$, indicating that the relationship between of the credit evaluation of online shopping and the purchase risk of consumers is significant. Therefore, $\mathrm{H} 1$ is valid.

According to the results in Table 6 , the estimate of $B_{2}$ is 0.486 , and the regression equation that predicts $M_{L S}$ with $V_{C E}$ is $M_{L S}=1.356+0.486 V_{C E}$. When the score of credit evaluation of online shopping increases, the score of logistics service increases. In addition, the $\mathrm{p}$-value is less than $\alpha$ (significance level $=0.05)$. Thus, the result of the hypothesis testing $\left(\mathrm{H}_{0}: \mathrm{B}_{2}=0\right)$ is rejection, that is, $\mathrm{B}_{2} \neq 0$, indicating that the linear relationship between logistics service and credit evaluation of online shopping is significant. Moreover, the regression equation that predicts $V_{P R}$ together with $V_{C E}$ and $M_{L S}$ is $V_{P R}=1.013-0.295 V_{C E}-0.179 M_{L S}$, where the estimate of $\mathrm{B}_{3}$ is -0.295 greater than the estimate of $B_{1}=-0.382$. The effect of $B_{3}$ on the purchase risk of consumers is less than the effect of $\mathrm{B}_{1}$ on the purchase risk of consumers, and the estimate of $C_{1}$ is -0.179 . The $\mathrm{p}$-value is less than $\alpha$ (significance level $=0.05$ ). Thus, the results of the hypothesis testing $\left(\mathrm{H}_{0}: \mathrm{B}_{3}=0\right)$ and $\left(\mathrm{H}_{0}: \mathrm{C}_{1}=0\right)$ are rejection, that is, $B_{3} \neq 0$ and $C_{1} \neq 0$, indicating that the linear relationship between credit evaluation of online shopping and the purchase risk of consumers and that between logistics service and the purchase risk of consumers are significant. Therefore, logistics services have a partial mediating effect on the relationship between the credit evaluation of online shopping and the purchase risk of consumers. H4 is valid.

Table 3. Analysis results of KMO and Bartlett's test.

\begin{tabular}{lll}
\hline \multicolumn{1}{l}{ Testing } & Result \\
\hline \multicolumn{2}{l}{ Kaiser-Meyer-Olkin Measure of Sampling Adequacy. } & 0.875 \\
& Approx. Chi-Square & 2180.215 \\
\multirow{2}{*}{ Bartlett's Test of Sphericity } & Degree of freedom & 210 \\
& Significance (p-value) & 0.000 \\
\hline
\end{tabular}


Table 4. Rotated component matrix.

\begin{tabular}{|c|c|c|c|c|c|c|c|}
\hline \multirow{2}{*}{ Risk factor } & \multicolumn{6}{|c|}{ Component } & \multirow{2}{*}{ Communality } \\
\hline & 1 & 2 & 3 & 4 & 5 & 6 & \\
\hline $\mathrm{B} 10$ & 0.881 & 0.210 & 0.113 & 0.059 & 0.104 & 0.040 & 0.830 \\
\hline B9 & 0.848 & 0.241 & 0.091 & 0.187 & 0.062 & 0.080 & 0.845 \\
\hline B11 & 0.830 & 0.295 & 0.057 & 0.194 & 0.107 & 0.127 & 0.739 \\
\hline B12 & 0.672 & 0.069 & 0.021 & 0.323 & 0.361 & 0.216 & 0.549 \\
\hline B7 & 0.522 & 0.252 & 0.245 & 0.008 & 0.352 & 0.169 & 0.847 \\
\hline B20 & 0.299 & 0.798 & 0.071 & 0.281 & 0.188 & 0.029 & 0.808 \\
\hline B21 & 0.285 & 0.785 & 0.093 & 0.295 & 0.125 & -0.021 & 0.788 \\
\hline B19 & 0.306 & 0.711 & 0.018 & 0.126 & 0.408 & 0.076 & 0.727 \\
\hline B6 & -0.154 & 0.139 & 0.784 & 0.097 & -0.025 & 0.243 & 0.714 \\
\hline $\mathrm{B} 2$ & 0.275 & 0.001 & 0.778 & 0.068 & 0.072 & 0.152 & 0.680 \\
\hline B1 & 0.088 & -0.011 & 0.745 & 0.201 & 0.266 & 0.077 & 0.559 \\
\hline B5 & 0.269 & 0.345 & 0.504 & -0.135 & 0.035 & 0.306 & 0.842 \\
\hline B14 & 0.153 & 0.355 & 0.213 & 0.777 & 0.152 & 0.145 & 0.793 \\
\hline B15 & 0.153 & 0.561 & 0.170 & 0.590 & 0.055 & 0.262 & 0.779 \\
\hline B17 & 0.100 & 0.167 & 0.236 & 0.298 & 0.762 & 0.123 & 0.638 \\
\hline B18 & 0.451 & 0.285 & 0.022 & 0.125 & 0.577 & 0.061 & 0.604 \\
\hline B16 & 0.201 & 0.300 & 0.089 & 0.027 & 0.548 & 0.407 & 0.806 \\
\hline B3 & 0.101 & 0.048 & 0.318 & 0.160 & 0.051 & 0.815 & 0.771 \\
\hline B4 & 0.135 & -0.025 & 0.280 & 0.266 & 0.284 & 0.723 & 0.648 \\
\hline B8 & 0.397 & 0.438 & 0.112 & -0.237 & 0.166 & 0.450 & 0.849 \\
\hline Average & & & & & & & 0.743 \\
\hline
\end{tabular}

Table 5. Results of reliability analysis.

\begin{tabular}{|c|c|c|c|c|}
\hline \multicolumn{2}{|l|}{ Name of variable } & \multirow{2}{*}{$\begin{array}{l}\text { Cronbach's } \boldsymbol{\alpha} \\
0.834\end{array}$} & \multirow{2}{*}{$\begin{array}{l}\text { Number of items } \\
6\end{array}$} & \multirow{2}{*}{$\begin{array}{l}\text { Overall Cronbach's } \boldsymbol{\alpha} \\
0.834\end{array}$} \\
\hline Credit evaluation of online $\mathrm{s}$ & & & & \\
\hline \multirow{5}{*}{ Purchase risk of consumers } & Store risk & 0.694 & 3 & \multirow{5}{*}{0.926} \\
\hline & Money risk & 0.756 & 4 & \\
\hline & Product risk & 0.896 & 5 & \\
\hline & Delivery risk & 0.863 & 3 & \\
\hline & Time risk & 0.723 & 3 & \\
\hline \multicolumn{2}{|c|}{ Purchase intention of consumers } & 0.863 & 4 & 0.863 \\
\hline \multicolumn{2}{|l|}{ Logistics service } & 0.786 & 4 & 0.786 \\
\hline
\end{tabular}

Table 6. Analysis results of the research hypotheses $\mathrm{H} 1$ and $\mathrm{H} 4$.

\begin{tabular}{|c|c|c|c|c|c|c|c|}
\hline \multirow{2}{*}{ Hypothesis } & \multirow{2}{*}{$\begin{array}{l}\text { Dependent } \\
\text { variable }\end{array}$} & \multirow{2}{*}{ Model } & \multicolumn{2}{|c|}{ Unstandardized Coefficients } & \multirow{2}{*}{$\begin{array}{l}\text { Standardized } \\
\text { Coefficients }\end{array}$} & \multirow{2}{*}{ t test } & \multirow{2}{*}{$\begin{array}{l}\text { Significance } \\
\text { (P-value) }\end{array}$} \\
\hline & & & B & Std. Error & & & \\
\hline \multirow{2}{*}{ H1 } & \multirow{2}{*}{$V_{P R}$} & Constant & 0.771 & 0.080 & \multirow[b]{2}{*}{-0.632} & 9.690 & 0.000 \\
\hline & & $V_{C E}$ & -0.382 & 0.037 & & -10.215 & 0.000 \\
\hline \multirow{5}{*}{$\mathrm{H} 4$} & \multirow{2}{*}{$M_{L S}$} & Constant & 1.356 & 0.168 & & 8.063 & 0.000 \\
\hline & & $V_{C E}$ & 0.486 & 0.079 & 0.441 & 6.154 & 0.000 \\
\hline & \multirow{3}{*}{$V_{P R}$} & Constant & 1.013 & 0.088 & & 11.527 & 0.000 \\
\hline & & $V_{C E}$ & -0.295 & 0.039 & -0.488 & -7.625 & 0.000 \\
\hline & & $M_{L S}$ & -0.179 & 0.035 & -0.326 & -5.092 & 0.000 \\
\hline
\end{tabular}

Table 7. Analysis results of the research hypotheses $H 2$ and $H 5$.

\begin{tabular}{|c|c|c|c|c|c|c|c|}
\hline \multirow{2}{*}{ Hypothesis } & \multirow{2}{*}{$\begin{array}{l}\text { Dependent } \\
\text { variable }\end{array}$} & \multirow{2}{*}{ Model } & \multicolumn{2}{|c|}{ Unstandardized Coefficients } & \multirow{2}{*}{$\begin{array}{l}\text { Standardized } \\
\text { Coefficients }\end{array}$} & \multirow{2}{*}{ t test } & \multirow{2}{*}{$\begin{array}{l}\text { Significance } \\
\text { (P-value) }\end{array}$} \\
\hline & & & B & Std. Error & & & \\
\hline \multirow{2}{*}{$\mathrm{H} 2$} & \multirow{2}{*}{$V_{P I}$} & Constant & 2.239 & 0.056 & \multirow[b]{2}{*}{-0.424} & 40.010 & 0.000 \\
\hline & & $V_{P R}$ & -0.806 & 0.138 & & -5.863 & 0.000 \\
\hline \multirow{5}{*}{ H5 } & \multirow{2}{*}{$M_{L S}$} & Constant & 2.338 & 0.050 & & 46.891 & 0.000 \\
\hline & & $V_{P R}$ & -0.988 & 0.123 & -0.541 & -8.064 & 0.000 \\
\hline & \multirow{3}{*}{$V_{P I}$} & Constant & 1.460 & 0.208 & & 7.031 & 0.000 \\
\hline & & $V_{P R}$ & -0.477 & 0.157 & -0.251 & -3.045 & 0.003 \\
\hline & & $M_{L S}$ & 0.333 & 0.086 & 0.320 & 3.883 & 0.000 \\
\hline
\end{tabular}


Table 8. Regression analysis of the purchase risk of consumers on the purchase intention of consumers.

\begin{tabular}{|c|c|c|c|c|c|c|}
\hline \multirow{2}{*}{$\begin{array}{l}\text { Dependent } \\
\text { variable }\end{array}$} & \multirow{2}{*}{ Model } & \multicolumn{2}{|c|}{ Unstandardized Coefficients } & \multirow{2}{*}{$\begin{array}{l}\text { Standardized } \\
\text { Coefficients }\end{array}$} & \multirow{2}{*}{ t test } & \multirow{2}{*}{$\begin{array}{l}\text { Significance } \\
\text { (P-value) }\end{array}$} \\
\hline & & $\mathbf{B}$ & Std. Error & & & \\
\hline \multirow{7}{*}{$\begin{array}{l}\text { Purchase } \\
\text { intention of } \\
\text { consumers }\end{array}$} & Constant & 2.239 & 0.056 & & 40.210 & 0.000 \\
\hline & Product risk & -0.213 & 0.056 & -0.274 & -3.815 & 0.000 \\
\hline & Personal information security risk & -0.037 & 0.056 & -0.048 & -0.671 & 0.503 \\
\hline & Money risk & -0.178 & 0.056 & -0.230 & -3.194 & 0.002 \\
\hline & Delivery risk & -0.148 & 0.056 & -0.191 & -2.655 & 0.009 \\
\hline & Time risk & -0.146 & 0.056 & -0.188 & -2.618 & 0.010 \\
\hline & Store risk & -0.083 & 0.056 & -0.107 & -1.481 & 0.141 \\
\hline
\end{tabular}

Table 9. Analysis results of the research hypotheses $H 3$ and $H 6$.

\begin{tabular}{|c|c|c|c|c|c|c|c|}
\hline \multirow{2}{*}{ Hypothesis } & \multirow{2}{*}{$\begin{array}{l}\text { Dependent } \\
\text { variable }\end{array}$} & \multirow{2}{*}{ Model } & \multicolumn{2}{|c|}{ Unstandardized Coefficients } & \multirow{2}{*}{$\begin{array}{l}\text { Standardized } \\
\text { Coefficients }\end{array}$} & \multirow{2}{*}{ t test } & \multirow{2}{*}{$\begin{array}{l}\text { Significance } \\
\text { (P-value) }\end{array}$} \\
\hline & & & B & Std. Error & & & \\
\hline \multirow{2}{*}{ H3 } & \multirow{2}{*}{$V_{P I}$} & Constant & 1.174 & 0.173 & \multirow{3}{*}{0.459} & 6.768 & 0.000 \\
\hline & & $V_{C E}$ & 0.527 & 0.082 & & 6.470 & 0.000 \\
\hline \multirow{5}{*}{ H6 } & \multirow{2}{*}{$M_{L S}$} & Constant & 1.356 & 0.168 & & 8.063 & 0.000 \\
\hline & & $V_{C E}$ & 0.486 & 0.079 & \multirow[t]{2}{*}{0.441} & 6.154 & 0.000 \\
\hline & \multirow{3}{*}{$V_{P I}$} & Constant & 0.730 & 0.196 & & 3.720 & 0.000 \\
\hline & & $V_{C E}$ & 0.368 & 0.086 & 0.320 & 4.261 & 0.000 \\
\hline & & $M_{L S}$ & 0.327 & 0.078 & 0.314 & 4.182 & 0.000 \\
\hline
\end{tabular}

According to Table 6, the indirect effect $\mathrm{a} \times \mathrm{b}=0.486 \times(-0.179)$, the direct effect $\mathrm{c}^{\prime}=-0.295$, and the total effect $\mathrm{c}=-0.382=\mathrm{a} \times \mathrm{b}+\mathrm{c}^{\prime}$. Thus, the mediation proportion is equal to $22.77 \%=(0.486 \times(-0.179)) /(-0.382)$. The proportion of the effect of the credit evaluation of online shopping $\left(V_{C E}\right)$ on the purchase risk of consumers $\left(V_{P R}\right)$ mediated through logistics services $\left(M_{L S}\right)$ is $22.77 \%$.

\subsubsection{Relationship Between the Purchase Risk of Consumers and the Purchase Intention of Consumers}

Regarding the relationship between the purchase risk of consumers $\left(V_{P R}\right)$ and the purchase intention of consumers $\left(V_{P I}\right)$, the hypotheses are as follows:

$\mathrm{H} 2$ : The purchase risk of consumers has a negative effect on the purchase intention of consumers.

H5: Logistics services have a mediating effect on the relationship between the purchase risk and intention of consumers.

According to the results in Table 7, the estimate of $\mathrm{B}_{4}$ is -0.806 , and the regression equation that predicts $V_{P I}$ with $V_{P R}$ is $V_{P I}=2.239-0.806 V_{P R}$. When the score of the purchase risk of consumers decreases, the score of the purchase intention of consumers increases. In addition, the p-value is less than $\alpha$ (significance level $=0.05$ ). Thus, the result of the hypothesis testing $\left(\mathrm{H}_{0}\right.$ : $\left.\mathrm{B}_{4}=0\right)$ is rejection, that is, $\mathrm{B}_{4} \neq 0$, indicating that the linear relationship between the purchase risk of consumers and the purchase intention of consumers is significant. Therefore, $\mathrm{H} 2$ is valid.

According to the results in Table 7, the estimate of $\mathrm{B}_{5}$ is -0.988 , and the regression equation that predicts $M_{L S}$ with $V_{P R}$ is $M_{L S}=2.338-0.988 V_{P R}$. When the score of the purchase risk of consumers decreases, the score of logistics service increases. In addition, the $\mathrm{p}$-value is less than $\alpha$ (significance level $=0.05$ ). Thus, the result of the hypothesis testing $\left(\mathrm{H}_{0}: \mathrm{B}_{5}=0\right)$ is rejection, that is, $\mathrm{B}_{5} \neq 0$, indicating that the linear relationship between logistics service and the purchase risk of consumers is significant. Moreover, the regression equation that predicts
$V_{P I} \quad$ together with $V_{P R}$ and $M_{L S}$ is $V_{P I}=1.460-0.477 V_{P R}+0.333 M_{L S}$, where the estimate of $\mathrm{B}_{6}$ is -0.477 greater than the estimate of $\mathrm{B}_{4}=-0.806$. The effect of $\mathrm{B}_{6}$ on the purchase intention of consumers is less than the effect of $\mathrm{B}_{4}$ on the purchase intention of consumers, and the estimate of $\mathrm{C}_{2}$ is 0.333 . The $\mathrm{p}$-value is less than $\alpha$ (significance level=0.05). Thus, the results of the hypothesis testing $\left(\mathrm{H}_{0}\right.$ : $\left.\mathrm{B}_{6}=0\right)$ and $\left(\mathrm{H}_{0}: \mathrm{C}_{2}=0\right)$ are rejection, that is, $\mathrm{B}_{6} \neq 0$ and $\mathrm{C}_{2} \neq 0$, indicating that the linear relationship between the purchase intention of consumers and the purchase risk of consumers and that between logistics service and the purchase intention of consumers are significant. Therefore, logistics services have a partial mediating effect on the relationship between the purchase intention of consumers and the purchase risk of consumers. H5 is valid.

According to Table 7 , the mediation proportion is equal to $40.82 \%=((-0.988) \times 0.333) /(-0.806)$, where the indirect effect $\mathrm{a} \times \mathrm{b}=(-0.988) \times 0.333$, the direct effect $\mathrm{c}^{\prime}=-0.477$, and the total effect $\mathrm{c}=-0.806=\mathrm{a} \times \mathrm{b}+\mathrm{c}$. Thus, the proportion of the effect of the purchase risk of consumers $\left(V_{P R}\right)$ on the purchase intention of consumers $\left(V_{P I}\right)$ mediated through logistics services $\left(M_{L S}\right)$ is $40.82 \%$.

The above analysis demonstrates that the purchase risk of consumers has a negative effect on their purchase intention. The purchase risk of consumers can be divided into product risk, personal information security risk, money risk, delivery risk, time risk, and store risk. The main risks affecting the purchase intention of consumers are further discussed below.

Table 8 shows that the p-values of personal information security risk and store risk are 0.503 and 0.141 respectively, and both are greater than $\alpha$ (significance level $=0.05$ ). These outcomes indicate that the personal information security risk and store risk have no significant effect on the purchase risk of consumers. The p-values of the remaining four risks are all less than $\alpha$ (significance level $=0.05$ ), indicating that they have a significant effect on the purchase risks of consumers. The regression coefficients corresponding to these four risks are all 
negative numbers. The regression coefficient corresponding to product risk is -0.213 , that corresponding to money risk is -0.178 , that corresponding to delivery risk is -0.148 , and that corresponding to time risk is -0.146 . Reducing these four risks can increase the purchase intention of consumers.

\subsubsection{Relationship Between the Credit Evaluation of Online Shopping and the Purchase Intention of Consumers}

Regarding the relationship between the credit evaluation of online shopping $\left(V_{C E}\right)$ and the purchase intention of consumers $\left(V_{P I}\right)$, the hypotheses are as follows:

H3: Credit evaluation of online shopping has a positive effect on the purchase intention of consumers.

H6: Logistics services have a mediating effect on the relationship between the credit evaluation of online shopping and the purchase intention of consumers.

According to the results in Table 9 , the estimate of $\mathrm{B}_{7}$ is 0.527 , and the regression equation that predicts $V_{P I}$ with $V_{C E}$ is $V_{P I}=1.174+0.527 V_{C E}$. When the score of the credit evaluation of online shopping increases, the score of the purchase intention of consumers increases. In addition, the p-value is less than $\alpha$ (significance level $=0.05$ ). Thus, the result of the hypothesis testing $\left(\mathrm{H}_{0}: \mathrm{B}_{7}=0\right)$ is rejection, that is, $\mathrm{B}_{7} \neq 0$. The linear relationship between the credit evaluation of online shopping and the purchase intention of consumers is significant. Therefore, $\mathrm{H} 3$ is valid.

According to the results in Table 9, the estimate of $\mathrm{B}_{8}$ is 0.486 , and the regression equation that predicts $M_{L S}$ with $V_{C E}$ is $M_{L S}=1.356+0.486 V_{C E}$. When the score of the credit evaluation of online shopping increases, the score of logistics service increases. In addition, the p-value is less than $\alpha$ (significance level $=0.05$ ). Thus, the result of the hypothesis testing $\left(\mathrm{H}_{0}: \mathrm{B}_{8}=0\right)$ is rejection, that is, $\mathrm{B}_{8} \neq 0$. The linear relationship between logistics service and the credit evaluation of online shopping is significant. Moreover, the regression equation that predicts $V_{P I}$ together with $V_{C E}$ and $M_{L S}$ is $V_{P I}=0.730+0.368 V_{C E}+0.327 M_{L S}$, where the estimate of $\mathrm{B}_{9}$ is 0.368 less than the estimate of $\mathrm{B}_{7}=0.527$. The effect of $\mathrm{B}_{9}$ on the purchase intention of consumers is less than the effect of $B_{7}$ on the purchase intention of consumers, and the estimate of $\mathrm{C}_{3}$ is 0.327 . The $\mathrm{p}$-value is less than $\alpha$ (significance level=0.05). Thus, the results of the hypothesis testing $\left(\mathrm{H}_{0}\right.$ : $\left.\mathrm{B}_{9}=0\right)$ and $\left(\mathrm{H}_{0}: \mathrm{C}_{3}=0\right)$ are rejection, that is, $\mathrm{B}_{9} \neq 0$ and $\mathrm{C}_{3} \neq 0$. That the linear relationship between the purchase intention of consumers and the credit evaluation of online shopping and that between logistics service and the purchase intention of consumers are significant. Therefore, the results show that logistics services have a partial mediating effect on the relationship between the purchase intention of consumers and the credit evaluation of online shopping. H6 is valid.

According to Table 9, the mediation proportion is equal to $30.16 \%=(0.486 \times 0.327) / 0.527$, where the indirect effect $\mathrm{a} \times \mathrm{b}=0.486 \times 0.327$, the direct effect $\mathrm{c}^{\prime}=0.368$, and the total effect $\mathrm{c}=0.527=\mathrm{a} \times \mathrm{b}+\mathrm{c}$ '. Thus, the proportion of the effect of the credit evaluation of online shopping $\left(V_{C E}\right)$ on the purchase intention of consumers $\left(V_{P I}\right)$ mediated through logistics services $\left(M_{L S}\right)$ is $30.16 \%$.

\subsection{Discussion of Analysis Results}

According to the above analysis results, the three main results explained as follows.

First, the purchase risk of consumers has a significant negative effect on the purchase intention of consumers, and logistics services have a partial mediating effect on the relationship between the purchase risk of consumers and the purchase intention of consumers.

In $\mathrm{C} 2 \mathrm{C}$ electronic transactions, consumers have concerns about online shopping due to its various risks. When consumers are sensitive to risk, their willingness to buy is affected. This study analyzes the six components of purchase risk of consumers in the face of their purchase intention and finds that product risk, money risk, delivery risk, and time risk have a significant negative effect on the purchase intention of consumers. The quality of the products received by consumers online, the possible monetary losses that consumers may incur, the effectiveness of product delivery, and the time spent on online shopping all have an effect on the purchase intention of consumers. When these risks are reduced, the purchase intention of consumers increases.

Logistics services are an indispensable part of $\mathrm{C} 2 \mathrm{C}$ electronic transactions. As part of logistics services, the delivery link can improve the quality of logistics services by reducing delivery risks. To reduce the purchase risk of consumers, especially delivery risk, sellers inevitably choose better logistics service companies and strive to provide better logistics services. This study posits that sellers provide better logistics services to reduce the purchase risk of consumers, and improving logistics service capabilities strengthens the purchase intention of consumers. The results show that logistics services have a partial mediating effect on the relationship between the purchase risk and intention of consumers.

Second, the credit evaluation of online shopping has a negative effect on the purchase risk of consumers, and logistics services have a partial mediating effect on the relationship between the credit evaluation of online shopping and the purchase risk of consumers.

In the $\mathrm{C} 2 \mathrm{C}$ electronic transactions, buyers can judge the quality of products based on the seller's credit evaluation. Consumers can buy products with more suitable quality to reduce their purchase risk. Moreover, a good credit evaluation can reduce product risk, money risk, and time risk. When the seller's credit rating is good, the risk of the product purchased by the consumer is reduced. The possibility that the consumer may receive a product that is inferior or inconsistent with expectations becomes low. In addition, the possibility of consumer online shopping disputes resulting in monetary loss or additional prices is reduced, reducing the money risk of consumers' online shopping. The time risk caused by consumers' return and exchange and the time to collect product information online is reduced as well.

Logistics services, as a part of $\mathrm{C} 2 \mathrm{C}$ e-commerce credit evaluation, have an important influence on the credit evaluation of online shopping. To improve their credit evaluation, sellers 
must provide good logistics services. A perfect credit evaluation can drive the development of logistics services, and good logistics services can reduce the purchase risk of consumers. Therefore, logistics services have a partial mediating effect on the relationship between the credit evaluation of online shopping and the purchase risk of consumers.

Finally, the credit evaluation of online shopping has a positive effect on purchase intention of consumers, and logistics services have a partial mediating effect on the relationship between the credit evaluation of online shopping and the purchase intention of consumers.

In $\mathrm{C} 2 \mathrm{C}$ electronic transactions, the higher the seller's credit rating, the higher the purchase intention of consumers. Logistics service is a part of the credit evaluation of online shopping. To obtain better credit evaluation, sellers need to improve their logistics service capabilities. By directly improving the logistics service capability, sellers indirectly increasing the purchase intention of consumers. Therefore, logistics services have a partial mediating effect on the relationship between the credit evaluation of online shopping and the purchase intention of consumers.

\section{Conclusion}

This paper studies the effect of online shopping credit evaluation on customer purchase risk, and considers logistics services as the mediating variable. According to the analysis results, the following two conclusions are put forward.

The first point is that sellers should improve their ability to serve consumers and, in turn, their credit evaluation. Online shopping is an emerging shopping method that is different from traditional shopping channels. Its transaction methods and transaction environment are very different from those in the past. In shopping, consumers can only learn about products by referring to the seller's credit evaluation. The better the seller's credit rating, the lower the product risk, time risk, and money risk of consumers.

First, sellers need to strengthen the quality control of the products they sell, try to improve the authenticity of the information displayed on the website, ensure the quality of the products more, and truly be oriented to the needs of consumers Providing good products and services can not only directly improve the seller's credit evaluation but also reduce the product risk of consumers shopping online.

Second, sellers should provide more easy-to-understand product recommendations and accurate descriptions of product information to help online consumers understand products more easily and clearly to reduce the time consumed by consumers searching for information online and the time risk caused by buyers' return and exchange. Delivery speed and logistics services are part of the seller's credit evaluation. The seller should deliver the goods in time after the consumer places the order and choose a good logistics service provider to increase the speed of the goods reaching the consumer. Doing so is conducive to improving the seller's credit evaluation, thereby reducing the time risk for consumers.
Finally, sellers should enhance their awareness of honest service, strengthen their communication skills with consumers, and be able to quickly and accurately resolve disputes with consumers. In so doing, the financial loss of consumers' online shopping is minimized, which can create a favorable impression among consumers and improve seller's credit evaluation.

The second point is that logistics service capabilities should be strengthened to increase the willingness of consumers to buy. C2C e-commerce platforms should strengthen the monitoring of logistics service providers. At present, China has many major logistics companies and express companies, and their service capabilities are uneven. Violent delivery and lost goods often occur during delivery. C2C e-commerce should establish a logistics service evaluation index system, strictly monitor logistics service providers, and screen out non-compliant logistics services from the source to provide sellers with better logistics service.

Express logistics companies should reduce the risk of cargo distribution and improve their service capabilities. In delivering goods, products are often lost, damaged, or surreptitiously replaced. Therefore, express logistics companies must also find solutions among themselves to reduce the cases of violent express delivery or lost goods during delivery. In addition, express logistics companies should strengthen the training of distribution personnel, improve the quality of distribution personnel, strengthen logistics service capabilities, and deliver goods to consumers accurately and efficiently.

Sellers should strengthen the delivery speed of the goods and deliver them on time. Delivery speed is also one of the important links of logistics services and an important factor affecting the buyer's delivery time. Therefore, sellers should deliver the goods on time to reduce the buyer's waiting time and improve the quality of logistics services.

\section{References}

[1] Yu, L., and Li, Y. J. (2016). Dilemma and Breakthrough of C2C E-commerce Credit Evaluation System. Knowledge Management Forum, 1 (02), 114-123.

[2] China Internet Network Information Center. (2018). The 41st Statistical Report on Internet Development in China. Available at: http://www.cac.gov.cn/2018-01/31/c_1122347026.htm [Accessed 1, 31, 2018].

[3] China Internet Network Information Center. (2016). Research Report on China's Online Shopping Market in 2015. Available at:

http://www.cac.gov.cn/files/pdf/cnnic/2015wangluogouwu.pd f[Accessed 6, 24, 2016].

[4] China e-Business Research Center. (2017). China E-commerce User Experience and Complaint Monitoring Report in 2017 (Part one). Available at: http://www.100ec.cn/zt/17tsjc/, [Accessed 8, 21, 2017].

[5] Yao, H. L. (2016). Problems in the Process of C2C Credit Information Evaluation and the Countermeasures. Harbin, Heilongjiang University. 
[6] Ji, W. J. (2013). Research on the Factors Influencing Online Consumers' Purchase Willingness. Jinan, Shandong University.

[7] Jing, M., and Zhou, Y. (2005). Study on Online Consumer Behavior Based on TAM and Perceived Risk. Shanghai Management Science, 5, 5-7.

[8] Pavlou, P. A. (2003). Consumer Acceptance of Electronic Commerce: Integrating Trust and Risk with the Technology Acceptance Model. International Journal of Electronic Commerce, 7 (3), 101-134.

[9] Han, S. G., Wu, J., and Chen, Q. (2016). Research on Index System of Logistics Service Quality Evaluation of Fresh Product E-commerce. Journal of Zhejiang Institute of Science and Technology, 36 (2), 138-143.

[10] Ye, N. Y., and Zhou, D. (2014). Conceptualization and Measurement Modeling of Consumer's Perceived Risk in Online Shopping. Journal of Industrial Engineering and Engineering Management, 28 (4), 88-94.

[11] Bauer, R. (1967). Consumer Behavior as Risk Taking. In: Cox, D. (Ed.), Risk Taking and Information Handling in Consumer Behavior. Cambridge, Mass, Harvard University Press.

[12] Engel, J. F. (1968). Risk Taking and Information Handling in Consumer Behavior. Journal of Marketing, 32 (3), 24-29.

[13] Hofacker, C. F., and Murphy, J. (1998). World Wide Web Banner Advertisement Copy Testing. European Journal of Marketing, 32 (7/8), 703-712.

[14] O'Mara, K., Cort, K., and Palin, G. A. (2011). Cross-national Empirical Study Investigating the Role of Purchasing Purpose has on the Country-of-origin Effect. International Journal of the Academic Business World, 2 (1), 99.

[15] Kaplan, L. B., Szybillo, G. J., and Jacoby, J. (1974). Components of Perceived Risk in Product Purchase: A Cross-validation. Journal of Applied Psychology, 59 (3), 287-291.

[16] Perraul, W. D., and Russ, F. (1974). Physical Distribution Service: A Neglected Aspect of Marketing Management. MUS Business Topics, 22 (2), 37-45.

[17] Mentzer, J. T., Gomes, R., and Krapfel, R. E. (1989). Physical distribution service: A Fundamental Marketing Concept. Journal of the Academy of Marketing Science, 17 (1), 53-62.
[18] Chen, L. (2012). Discussion on C2C Electronic Commerce Model. Shangqing, 51, 141-141.

[19] Garretson, J. A., and Clow, K. E. (1999). The Influence of Coupon Face Value on Service Quality Expectations, Risk Perceptions and Purchase Intentions in the Dental Industry. The Journal of Services Marketing, 13 (1), 59-72.

[20] Wu, K. W., Zhao, Y. X, and Zhu, Q. H. (2010). Review on Evaluation of Seller's Reputation in C2C, Online Market. Library and Information Service, 54 (14), 136-139+101.

[21] Liu, Y. W. (2009). The Effects of Reputation Systems in Online Marketplaces. Hefei, University of Science and Technology of China.

[22] Yu, B. Q., Wu, S. P., and Du, G. W. (2014). Branch Model Simulation for Express Logistics Service System Evaluation under Online Shopping. Chinese Journal of Management Science, 22 (12), 72-78.

[23] He, Y. Y., and Lv, Y. W. (2012). The Practical Research on the Influencing Factors of Logistic Service Quality and Customer Loyalty. China Business and Market, 26 (7), 79-82.

[24] Tang, H. (2013). The Research of Credit Evaluation System Based on Taobao C2C Payment Option. Shanghai, Shanghai University.

[25] MacKinnon, D. P. (2008). Introduction to Statistical Mediation Analysis. New York, Lawrence Erlbaum Associate.

[26] Sobel, M. E. (1982). Asymptotic Confidence Intervals for Indirect Effects in Structural Equation Models. Sociological methodology, 13, 290-312.

[27] Wang, Y. C., Wu, C. L., and Lee, Y. M. (2014). Development of the Work-Family Strength Scale for Working Parents in Taiwan. Chinese Journal of Guidance and Counseling, 41, $57-92$

[28] Lin, C. L., and Lin, M. J. (2007). The Validity and Reliability of Chinese Version of Loneliness Scale-The Example of the Elderly. The Journal of Guidance \& Counseling, 29 (2), 41-50.

[29] DeVellis, R. F. (1991). Scale development: Theory and applications. London, Sage Publications. 